\title{
Top up transfusions in neonates
}

There are four reasons for giving top up transfusions to preterm infants: to replace acute blood loss; to replace chronic blood loss; to treat hypotension; and to reverse the chronic anaemia that is characteristically seen at 7 to 8 weeks of age in preterm infants and earlier in survivors of haemolytic disease caused by blood group incompatibility.

\section{Replacement of acute blood loss}

A neonate who has suffered an acute intrapartum haemorrhage or postnatal haemorrhage must have an immediate blood transfusion. Ideally, $\mathrm{ABO}$ and $\mathrm{Rh}$ compatible blood that is less than two days old (checked by an emergency cross match) should be given, but in an emergency fresh, uncrossmatched, $\mathrm{O}$ negative blood can be used. Transfusion should be continued until the systolic blood pressure is greater than $40 \mathrm{mmHg}$ and the packed cell volume is $35-40 \%$. This aspect of neonatal transfusion is not contentious.

\section{Replacement of chronic blood loss}

A baby weighing $1000 \mathrm{~g}$ has a blood volume of $80 \mathrm{ml}$ of which about $35 \mathrm{ml}$ are red cells. His red cells have a shortened survival time and his erythropoietin production is suppressed. ${ }^{1}$ Severe illness may cause red cell haemolysis and depress the marrow. This is well recognised in sepsis, ${ }^{2}$ and probably also occurs in ill, hypoxic neonates on ventilators whose transfusion requirements considerably exceed their blood losses, either haemorrhagic or iatrogenic. It is iatrogenic blood losses, however, that pose a major problem for the critically ill preterm neonate. Despite the use of transcutaneous or continuous $\mathrm{PO}_{2}$ and $\mathrm{PCO}_{2}$ monitors he may require a minimum of eight to 10 blood gas analyses per day; in ill hypotensive infants transcutaneous monitors are unreliable, umbilical artery catheters with a transducer in their tip do not measure $\mathrm{PaCO}_{2}$ or $\mathrm{pH}$, and all continuous recording devices require calibration. As well as blood gas measurements, sick babies have multiple blood samples withdrawn for haematological, biochemical, and serological analyses.

Blood gases may be measured on a $100 \mu \mathrm{l}$ sample, and it is 20 years since Wilfrid Payne at the Hammersmith Hospital reported that he could do 10 biochemical investigations on $1 \mathrm{ml}^{3}$ Many neonatal paediatricians, however, have to work with laboratory services that are at best covertly uncooperative, and at worse overtly hostile to requests for ultramicroscopic analyses with the quick turn round essential for neonatal intensive care. This can result in unnecessarily large volumes of blood being sampled from neonates.

Three approaches have been used to maintain adequate haemoglobin concentrations in the baby. Transfusion may be carried out when he has had the equivalent of $1 \%$ of his birth weight removed as blood-that is, $10 \mathrm{ml}$ in the baby weighing $1000 \mathrm{~g}$, or when he has had $10 \%$ of his blood volume removed-that is, $8 \mathrm{ml}$ in the baby weighing $1000 \mathrm{~g}$. Both approaches are equivalent to permitting the loss of about one pint of blood from an adult. Alternatively, the blood may be transfused when the baby's packed cell volume (PCV) drops below some preset point. Whichever approach is used, it usually results in the baby having blood transfused with the same frequency, and at about the same PCV-that is, $35-40 \%$ when he is given about $15 \mathrm{ml} / \mathrm{kg}$ of packed red cells. These practices, and in particular the cut off point for PCV of $35-40 \%$, have never been evaluated in prospective randomised controlled trials and are based on two pieces of evidence, both of which I find convincing.

Firstly, many clinicians feel that when the PCV in an ill baby weighing less than $2000 \mathrm{~g}$ falls below $35-40 \%$ the baby deteriorates (my own belief is that the danger point is nearer $40 \%$ than $35 \%$ ). The baby may have increased apnoea, he may show signs of heart failure, develop a metabolic acidaemia, or his requirements for ventilatory support may increase. In addition, if the PCV is allowed to fall as low as $25-30 \%$, the volume of blood required to increase the PCV to $40 \%$ introduces problems of vascular overload.

Secondly, the physiological justification for this approach comes from evaluation of the data on systemic oxygen transport and tissue oxygen extraction in the neonate. ${ }^{4}$ There are three factors to be considered in systemic oxygen transport: cardiac output, PCV, and the position of the oxyhaemoglobin dissociation curve. The neonatal cardiovascular system is working at the limits of the Frank-Starling curve ${ }^{5}$ and has little if any capacity for maintaining tissue oxygen delivery by increasing cardiac output in the presence of anaemia. In the neonate the ability of the tissues to extract oxygen 
from the blood is seriously compromised by the left shifted oxyhaemoglobin dissociation curve, and this is made worse if the baby is already hypoxic because of severe lung disease. Thus it is logical to keep the PCV in the optimal range. I know of no data about the optimal PCV in neonates, but in animals the cardiac output begins to increase once the PCV falls below $35-40 \%$. $^{6}$ I have no doubt, therefore, that in the ill baby of very low birth weight the PCV must be kept above $35-40 \%$.

\section{Hypotension}

There is now a wealth of evidence that hypotension is bad for small babies. It is of clear aetiological importance in periventricular haemorrhage and periventricular leucomalacia, ${ }^{7}$ necrotising enterocolitis, and renal failure. Hypotensive babies with respiratory distress syndrome are more likely to die. $^{8}$ The normal blood pressure in the babies most likely to require transfusion-that is those less than 32 weeks old and weighing less than $1500 \mathrm{~g}$ averages $50-55 / 30-35 \mathrm{mmHg}$. Clinical experience suggests that the systolic pressure must be kept above $35-40 \mathrm{mmHg}$ and the mean above $25-30$ $\mathrm{mmHg}$.

When hypotension is seen after birth it is commonly due to a low blood volume. ${ }^{9}$ Later in the first week, hypotension may be due to volume depletion (blood sampling, dehydration), haemorrhage (from catheters, disseminated intravascular coagulation, or within the brain), drugs (tolazoline, pancuronium), or severe illness (sepsis). Furthermore, positive pressure ventilation can compromise venous return and cardiac function, and so it is particularly important to maintain a ventilated infant's blood volume. ${ }^{10}$

Although infusion of an inotropic drug such as dopamine can be valuable in severely ill babies, under most circumstances volume expansion is the appropriate treatment. For the reasons outlined above, if the PCV is less than $40 \%$ the transfusion should be given as blood $(10-15 \mathrm{ml} / \mathrm{kg}$ ), but if the PCV is over $40 \%$ a similar volume of plasma or albumin can be used.

\section{Late anaemia}

By 7 to 8 weeks of age, the haemoglobin concentration in many babies of less than $1500 \mathrm{~g}$ in weight has fallen to 7-8 $\mathrm{g} / \mathrm{dl}$, and similar haemoglobin concentrations may occur even earlier in infants who have had Coombs' positive haemolytic disease of the newborn. By this age, in the absence of lung disease and in the presence of a rise in haemoglobin A concentrations, a shift to the right of the oxygen dissociation curve, and improved cardiovascular function, tissue oxygen delivery remains good even at haemoglobin concentrations of $7-8 \mathrm{~g} / \mathrm{dl} .{ }^{4}$ If anaemia is accompanied by a good reticulocytosis $\left(>150 \times 10^{9} / \mathrm{l}\right)$ no treatment is indicated, in the expectation that the haemoglobin will rise spontaneously. If the haemoglobin falls below $7 \mathrm{~g} / \mathrm{dl}$, however, or if the infant feeds poorly, or is dyspnoeic at rest, $25-35 \mathrm{ml} / \mathrm{kg}$ of packed red cells should be transfused. ${ }^{11}$

\section{Risks of transfusion}

Neonatologists must of course minimise the need for transfusion by asking laboratory colleagues to cooperate by providing adequate ultramicroscopic analytical systems. We should minimise iatrogenic blood loss by complementing arterial blood gas analysis with some form of continuous blood gas monitoring system, either intravascular or transcutaneous, although we must acknowledge the limitations of transcutaneous monitoring for preventing retinopathy of prematurity. In particular, the occasional wildly inaccurate transcutaneous $\mathrm{PO}_{2}$ measurement means that several arterial blood samples for blood gas analyses will be needed every 24 hours in babies at risk from retinopathy of prematurity.

Although cases of neonatal acquired immune deficiency syndrome (AIDS) related to transfusion have been reported ${ }^{12}$ they occurred before testing of donors for human immunodeficiency virus (HIV) antibody had become routine and before groups at risk voluntarily stopped donating blood. In the current furore about AIDS neonatologists must try and maintain a sense of proportion. The likelihood of a neonate acquiring AIDS from donor blood in the United Kingdom is remote: it has been estimated at less than one case in 1000000 transfusions. ${ }^{13}$ This is less than the risk of developing or dying from hepatitis ${ }^{14}$ or contracting cytomegalovirus infection from the donor blood,${ }^{15}$ and much less than the risk of a baby weighing $1000 \mathrm{~g}$ dying if the systolic blood pressure and packed cell volume are allowed to remain below $40 \mathrm{mmHg}$ and $40 \%$, respectively. Indeed, for the past five years a much greater priority for neonatologists should have been to obtain donor blood that was free of cytomegalovirus infection rather than free of HIV. ${ }^{16}$

\footnotetext{
References

1 Oski FA, Naiman JL. Hematological problems in the newborn. Philadelphia: WB Saunders, 1982:21-4.

2 Blanchette VS, Zipursky A. Assessment of anemia in newborn infants. Clin Perinatol 1984;11:489-510.

3 Acharya PT, Payne WW. Blood chemistry of normal full term
} 
infants in the first 48 hours of life. Arch Dis Child 1965;40: $430-5$.

${ }^{4}$ Lister G, Moreau G, Moss M, Talner NS. Effects of alterations of oxygen transport on the neonate. Semin Perinatol 1984;8:192-204.

5 Rudolph AM. Organisation and control of the fetal circulation. In: Jones CT, Nathanielsz PW, eds. The physiological development of the fetus and newborn. London: Academic Press, 1975:343-54.

${ }^{6}$ Fan FC, Chen RYZ, Schuessler GB, Chien S. Effects of hematocrit variations on regional hemodynamics and oyxgen transport in the dog. Am J Physiol 1980;238:545-52.

${ }^{7}$ Lou H, Volpe JJ. Pathogenesis of hypoxic, ischaemic encephalopathy and germinal matrix haemorrhage. In: Roberton NRC, ed. Textbook of neonatology. Edinburgh: Churchill Livingstone, 1986:543-5.

${ }^{8}$ Roberton NRC. Management of hyaline membrane disease. Arch Dis Child 1979;54:838-41.

${ }^{9}$ Faxelius G, Raye J, Gutberlet R, et al. Red cell volume measurements and acute blood loss in high risk newborn infants. J Pediatr 1977;90:273-81.

${ }^{10}$ Roberton NRC. The care of neonates with respiratory failure. In: Chiswick ML, ed. Recent advances in perinatal medicine, No 1. Edinburgh: Churchill Livingstone, 1983:169-90.
"Wardrop CAJ, Holland BM, Veale KEA, Jones JG, Gray OP. Non-physiological anaemia of prematurity. Arch Dis Child 1978;53:855-60.

12 O'Duffy JF, Isles AF. Transfusion-induced AIDS in four premature babies. Lancet 1984;ii:1346.

13 Anonymous. Blood transfusion and AIDS. Br Med J 1987;294:192.

14 Bove JR. Transfusion-associated hepatitis and AIDS: what is the risk? N Engl J Med 1987;317:242-5.

15 Blajchman MA, Sheridan D, Rawls WE. Risks associated with blood transfusion in newborn babies. Clin Perinatol 1984;14:403-15

16 Yeager AS, Grumen FC, Hafleigh EB, Arvin AM, Bradley JS, Prober CG. Prevention of transfusion acquired cytomegalovirus in newborn infants. J Pediatr 1971;98:281-7.

\section{N R C ROBERTON \\ Rosie Maternity Hospital, Cambridge,}

(Present address: Riyadh Armed Forces Hospital, PO Box 7897, Riyadh 11159, Kingdom of Saudi Arabia.) 